\title{
Genetic variation at traditional and novel allozyme loci, applied to interactions between wild and reared Salmo salar L. (Atlantic salmon)
}

\author{
IAIN F. WILSON, ELIZABETH A. BOURKE \& THOMAS F. CROSS* \\ Department of Zoology, Lee Maltings, Prospect Row, University College, Cork, Ireland
}

\begin{abstract}
This study aimed to increase the number of allozyme loci which may be screened in the Atlantic salmon, Salmo salar L., particularly for use in investigating interactions between wild populations and reared strains. Three samples of wild salmon from Ireland, Scotland and Spain and one from a farmed strain of Norwegian origin were used as index samples. Other Irish samples were used in technique development. Ninety-one enzyme loci were resolved, including 21 not previously screened in $S$. salar. Thirteen loci were found to be variable, including three novel polymorphic loci (EST-5*, FBALD-3* and TPI-3*). Two novel alleles ( $s A A T-1,2^{*} 130$ and $s A A T-3^{*} 83$ ) were also detected. Levels of variability were lowest in the Spanish sample. The farmed strain had levels of $\bar{H}$ and $\bar{P}$ lower than those in the two other wild samples. Mean levels of $\bar{H}$ and $\bar{P}$ were higher than those reported previously in studies that used a smaller number of loci but confirm $S$. salar as one of the less variable salmonids. Nine of the 13 variable loci showed significant population differentiation, the most discriminatory being $m M E P-2^{*}$. The discriminatory power of the novel variable loci was in the middle of the range of those of the other loci. $\bar{D}$ values reflected the relative geographical locations from which the samples originated. There were significant clines in allele frequencies at $m M E P-2^{*}$ and TPI-3*. Fourteen enzyme loci including six variable loci were resolved in adipose fin.
\end{abstract}

Keywords: farmed line, genetic impact, geographical differentiation, novel allozymes, Salmo salar, wild populations.

\section{Introduction}

Natural populations of the Atlantic salmon, Salmo salar L., in western Europe are an important resource for commercial exploitation, angling tourism and as gene banks for the improvement of fish farm stocks. Reared stocks of this species often have reduced levels of genetic variability and often differ in allele frequencies from their ancestral populations (Cross, 1991). Natural populations of $S$. salar therefore face the possibility of being genetically altered as a result of interbreeding with farmed escapes or non-native fish planted in rivers for purposes of stock enhancement and that ascend rivers to spawn. Current discussions (Verspoor, 1988a; Maitland, 1989; Cross, 1991; Hindar et al., 1991) are, however, largely speculative and based on

${ }^{*}$ Correspondence. inferences from a limited number of relevant studies carried out on other species (for a review see Skaala et al., 1990). Informative studies of the genetic implications of population mixing in $S$. salar have been precluded by the absence of suitable genetic markers for distinguishing between native and non-native individuals in the wild and in experimental situations. In addition, the lack of suitable variation has also constrained the analysis of the extent of adaptive population differentiation (Ferguson, 1980).

Allozyme markers have already been identified which can be used to distinguish between European and North American S. salar (Ståhl, 1987) and individuals have been assigned to continent of origin with an error rate of less than 1 per cent (Verspoor \& Reddin, 1989). In addition, northern and southern European groups have been identified (Verspoor, 1988b). These markers can also distinguish between populations at the local level (e.g. Ståhl, 1987). For 
example, relative return rates of wild and non-native salmon have been estimated by comparing allele frequencies at $m M E P-2^{*}$ in Spanish rivers stocked with Scottish ova (Garcia de Leániz et al., 1989). A similar approach, using many polymorphic loci, is also regularly applied to discriminate between populations of Pacific salmonids in north-west America (e.g. Shaklee et al., 1991).

By using a suite of buffer systems and by screening for enzyme variants regularly assayed in populations of Pacific salmon (J. B. Shaklee, personal communication), we aimed to extend the number of loci surveyed in $S$. salar and to investigate genetic differences between farmed and wild populations of this species. In addition, we investigated the potential of using nondestructive adipose fin tissue biopsies to detect enzyme variation in $S$. salar.

\section{Materials and methods}

\section{Sample sites}

Samples of $S$. salar parr to be used for technique development were collected by electrofishing in the summer of 1991 from the unstocked River Abhann na Sceartán $(N=80)$ and from the stocked River Brogeen $(N=12)$, two tributaries of the River Blackwater, Co. Cork, Ireland. Brown trout $(S$. trutta) parr were excluded on the basis of morphological characteristics. Any hybrids overlooked were identified later by their GPI* genotypes (Vuorinen \& Piironen, 1984).

Three sites were then chosen as containing $S$. salar representative of wild, native populations with varying degrees of modification by stocking. In addition, a sample representative of the most common strain of salmon farmed in Ireland and Scotland was also chosen. These sources were as follows. (i) Blackwater which supports large native populations of $S$. salar. This river is stocked in the lower reaches by native fish but the index sample was collected farther upstream. (ii) Rio Esva (Asturias, Spain) which supports wild Spanish populations but has also been stocked with wild salmon from the River Shin and from other Spanish rivers. (iii) Shin (Kyle of Sutherland, Scotland) which supports wild Scottish populations and which to our knowledge has not been stocked with non-native fish. (iv) An Irishreared strain of Norwegian origin that is used by many salmon farms in Ireland, Scotland and Norway.

The three riverine samples of $S$. salar were collected by electrofishing, and the farmed sample was donated by a salmon farm in Co. Donegal,
Ireland. Each sample comprised 50 individuals that were dissected immediately on being killed and the tissues stored at $-70^{\circ} \mathrm{C}$. Samples of the Spanish and Scottish fish were delivered to Cork on dry ice. Adipose fin tissue samples were dissected from the salmon collected from the Blackwater tributaries and were stored at $-70^{\circ} \mathrm{C}$.

The shortest marine distances between the estuaries of rivers from which samples were collected were estimated and the latitudes noted. The farmed fish are known to have originated from several rivers along the southern west coast of Norway near Bergen.

\section{Electrophoresis}

Partially frozen tissue samples (approximately 250 $\mathrm{mg}$ ) were mechanically homogenized in $0.25 \mathrm{~mL}$ of the extractant buffer described by Aebersold et al. (1987), centrifuged at $1500 \mathrm{~g}$ for $15 \mathrm{~min}$ and subjected to horizontal electrophoresis using 12 per cent starch gels (Starchart, PO Box 268, Smithville, TX) in $210 \times 158 \times 6$ or $12 \mathrm{~mm}$ moulds. Gels were run between upper and lower cooling plates in which water circulated at $5^{\circ} \mathrm{C}$.

The buffers that provided the clearest resolution of the enzymes examined in the two samples used for technique development were then used to screen for enzyme variation in the four index samples. The six different optimum buffer systems and the tissues and stains used are reported in Table 1 along with the relative activities of the loci screened in adipose fin tissue. Loci are named according to Shaklee et al. (1990). $s A A T-1,2^{*}$ and $s A A T-3^{*}$ were interpreted after Johnson (1984), $S A A T-4^{*}$ (renumbered from $S A A T-3^{*}$ to $s A A T-4^{*}$ by Johnson, 1984), IDDH-1*, $I D D H-2^{*}$ (formerly $S d h-2$ and $S d h-1$, respectively) and $M D H-3,4^{*}$ following Cross \& Ward (1980), IDHP-3* following Cross \& Payne (1977), LDH-4* after Jordan (1990), $m M E P-2^{*}$ after Cross et al. (1979) and PGM-2* following Allendorf et al. (1982).

\section{Statistical analysis}

Allele frequencies were estimated from the genotype frequencies calculated from observation of the allozyme phenotypes on each gel. Allelic variants at $M D H-3,4^{*}$ and $s A A T-1,2^{*}$ were allocated to $M D H-3^{*}$ and $S A A T-1^{*}$, respectively. Because of the small number of expected genotypes in certain cases, samples were tested for deviation from HardyWeinberg expectation by using Fisher's exact test. Analysis of gene frequencies was performed by using 
Table 1 EC number and subunit structure of the 91 enzyme loci investigated in Salmo salar

\begin{tabular}{|c|c|c|c|c|c|c|}
\hline Locus $\dagger$ & EC no. & Structure & Buffer $\ddagger$ & Tissue\# & V/M§ & $\mathrm{AF}$ ๆ \\
\hline$m A A T-1^{*}$ & 2.6.1.1 & Dimer & 2 & $\mathbf{M}$ & $\mathbf{M}$ & - \\
\hline$m A A T-2^{*}$ & & & 2 & $\mathbf{M}$ & $\mathbf{M}$ & ++ \\
\hline$s A A T-1,2^{*}$ & & & 1 & $\mathrm{M}, \mathrm{H}$ & V & - \\
\hline sAAT-3* & & & 1,2 & $\mathrm{E}$ & V & ++ \\
\hline$s A A T-4^{*}$ & & & 1 & L & $\mathrm{V}$ & - \\
\hline$A C P^{*}$ & 3.1.3.2 & Unknown & 6 & $\mathrm{~L}, \mathrm{PC}, \mathrm{H}$ & n.s. & n.t. \\
\hline$A D A-1^{*}$ & 3.5.4.4 & Monomer & $2 a$ & $\mathrm{M}, \mathrm{L}$ & $\mathbf{M}$ & n.t. \\
\hline$A D A-2^{*}$ & & & $2 a$ & M,L,E,H & $\mathbf{M}^{\mathrm{r}}$ & n.t. \\
\hline$A D H^{*}$ & 1.1.1.1 & Dimer & 5,1 & $\mathrm{~L}$ & $\mathbf{M}^{\mathrm{r}}$ & - \\
\hline$A H-1^{*}$ & 4.2.1.3 & Monomer & 2 & $\mathrm{H}, \mathrm{B}, \mathrm{E}$ & n.s. & - \\
\hline$A H-2^{*}$ & & & 2 & $\mathrm{H}, \mathrm{B}, \mathrm{M}, \mathrm{L}$ & n.s. & ++ \\
\hline$A H-3^{*}$ & & & 2 & $\mathrm{H}, \mathrm{B}, \mathrm{M}, \mathrm{L}$ & n.s. & ++ \\
\hline$A H-4^{*}$ & & & 2 & $\mathbf{L}$ & n.s. & ++ \\
\hline$A K-1^{*}$ & 2.7 .4 .3 & Monomer & 3 & $\mathbf{M}$ & $\mathbf{M}$ & ++ \\
\hline$A K-2^{*}$ & & & 3 & $\mathbf{M}$ & $\mathbf{M}$ & ++ \\
\hline$A L A T-1^{*}$ & 2.6.1.2 & Dimer & 1 & L & n.s. & n.t. \\
\hline$A L A T-2^{*}$ & & & 1 & $\mathrm{M}, \mathrm{H}$ & n.s. & n.t. \\
\hline$C K-1^{*}$ & 2.7.3.2 & Dimer & 1 & $\mathbf{M}$ & $\mathbf{M}^{\mathrm{r}}$ & - \\
\hline$C K-2^{*}$ & & & 1 & $\mathbf{M}$ & M & - \\
\hline$C K-3^{*}$ & & & 1,3 & $\mathrm{E}$ & M & ++ \\
\hline$D L A-1^{*}$ & 1.8.1.4 & Monomer & 5,1 & $\mathrm{~B}, \mathrm{E}$ & $\mathbf{M}$ & n.t. \\
\hline$D I A-2^{*}$ & & & 5,1 & $\mathbf{L}, \mathbf{M}$ & M & n.t. \\
\hline$D I A-3^{*}$ & & & 5,1 & $\mathrm{H}$ & n.s. & n.t. \\
\hline ENO-1* & 4.2.1.11 & Dimer & $2 a$ & M & n.s. ${ }^{n}$ & n.t. \\
\hline$E N O-2^{*}$ & & & $2 a$ & $\mathrm{H}$ & n.s. ${ }^{n}$ & n.t. \\
\hline$E S T-1^{*}$ & 3.1.1.- & Monomer & 1 & $\mathbf{L}$ & $\mathbf{M}$ & - \\
\hline EST-2* & & & 1 & L & M & - \\
\hline EST-3* & & & 1 & $\mathbf{L}$ & $\mathbf{M}$ & - \\
\hline EST-4* & & & 1 & $\mathbf{L}$ & $\mathbf{M}$ & - \\
\hline EST-5* & & & 1 & $\mathbf{L}$ & $\mathrm{V}^{\mathrm{n}}$ & - \\
\hline$F B A L D-1^{*}$ & 4.1.2.13 & Tetramer & $2 a$ & $\mathrm{H}$ & $M^{n}$ & - \\
\hline$F B A L D-2^{*}$ & & & $2 a$ & H,E,B & $\mathbf{M}^{\mathrm{n}}$ & ++ \\
\hline$F B A L D-3^{*}$ & & & 2 & $\mathrm{E}, \mathrm{B}$ & $\mathrm{V}^{\mathrm{n}}$ & - \\
\hline$F H-1^{*}$ & 4.2.1.2 & Tetramer & 3 & L,B,M,H,E & $\mathbf{M}$ & +++ \\
\hline$F H-2^{*}$ & & & 3 & $\mathrm{~L}, \mathrm{~B}, \mathrm{M}, \mathrm{H}$ & $\mathbf{M}$ & +++ \\
\hline$b G A L A-1 *$ & 3.2 .1 .23 & Unknown & 5 & L,M,E,PC & n.s. ${ }^{n}$ & n.t. \\
\hline$b G A L A-2^{*}$ & & & 5 & L,M;B & n.s. ${ }^{n}$ & n.t. \\
\hline GAPDH-1* & 1.2.1.12 & Tetramer & 2 & $\mathrm{E}$ & $\mathbf{M}$ & +++ \\
\hline$G D A^{*}$ & 3.5.4.3 & Monomer & 5 & $\mathbf{L}$ & n.s. ${ }^{n}$ & n.t. \\
\hline$b G L U A^{*}$ & 3.2 .1 .30 & Unknown & 5 & $\mathrm{H}, \mathrm{M}, \mathrm{L}, \mathrm{PC}$ & n.s. ${ }^{\mathrm{n}}$ & n.t. \\
\hline G3PDH-1* & 1.1.1.8 & Dimer & 2 & M & $\mathbf{M}^{\mathrm{r}}$ & - \\
\hline GPI-1,2* & 5.3.1.9 & Dimer & 1 & $\mathbf{M}$ & $\mathbf{M}^{\mathrm{r}}$ & ++ \\
\hline GPI-3* & & & 1 & $\mathrm{~L}, \mathbf{M}$ & $\mathbf{M}^{\mathrm{r}}$ & +++ \\
\hline$G R^{*}$ & 1.6.4.2 & Dimer & 2 & $\mathrm{E}$ & n.s. ${ }^{n}$ & n.t. \\
\hline$I D D H-1,2^{*}$ & 1.1.1.14 & Tetramer & 4 & $\mathbf{L}$ & $\mathrm{V}$ & - \\
\hline$I D H P-1^{*}$ & 1.1.1.42 & Dimer & 3 & $\mathrm{M}, \mathrm{H}, \mathrm{E}$ & $\mathbf{M}$ & + \\
\hline$I D H P-2 *$ & & & 3 & $\mathrm{~L}, \mathrm{E}$ & M & +++ \\
\hline IDHP-3* & & & 2,3 & $\mathrm{~L}, \mathrm{E}$ & V & +++ \\
\hline$L D H-1^{*}$ & 1.1.1.27 & Tetramer & 1 & $\mathbf{M}$ & $\mathbf{M}$ & - \\
\hline$L D H-2^{*}$ & & & 1 & M & M & - \\
\hline LDH-3* & & & 1 & $\mathrm{H}, \mathrm{M}$ & $\mathbf{M}$ & +++ \\
\hline$L D H-4^{*}$ & & & 1 & L & V & +++ \\
\hline$L D H-5 *$ & & & 1 & $\mathrm{E}$ & $\mathbf{M}^{\mathrm{r}}$ & - \\
\hline$L G L^{*}$ & 4.4.1.5 & Dimer & $2 a$ & $\mathbf{M}$ & $\mathbf{M}^{\mathrm{r}}$ & n.t. \\
\hline$M D H-1^{*}$ & 1.1.1.37 & Dimer & 2,3 & L,H,B,E & $\mathbf{M}^{\mathrm{r}}$ & +++ \\
\hline
\end{tabular}


Table 1 Continued

\begin{tabular}{|c|c|c|c|c|c|c|}
\hline Locus $\dagger$ & EC no. & Structure & Buffer $\neq$ & Tissue\# & V/M§ & AFף \\
\hline$M D H-2^{*}$ & & & 2,3 & $\mathrm{H}, \mathrm{B}, \mathrm{E}$ & M & - \\
\hline$M D H-3,4^{*}$ & & & 3 & $\mathrm{H}, \mathbf{M}$ & V & ++ \\
\hline$m M E P-1^{*}$ & 1.1.1.40 & Tetramer & 3 & $\mathbf{M}$ & $\mathbf{M}$ & + \\
\hline$m M E P-2^{*}$ & & & 3 & M & V & + \\
\hline$s M E P-1,2^{*}$ & & & 3 & M & $\mathbf{M}$ & + \\
\hline$m M E^{*}$ & 1.1.1.38 & Tetramer & 3 & M & $\mathbf{M}^{r}$ & - \\
\hline$M P I-1^{*}$ & 5.3.1.8 & Monomer & 2 & M & n.s. ${ }^{n}$ & n.t. \\
\hline MPI-2* & & & 5 & L,H,E,M & M & n.t. \\
\hline$N T P-1 *$ & 3.6.1.19 & Dimer & 1 & L,M,E,H,B & $\mathbf{M}^{\mathrm{n}}$ & n.t. \\
\hline$N T P-2^{*}$ & & & 1 & L,M,E,H,B & $\mathbf{M}^{\mathrm{n}}$ & n.t. \\
\hline$N T P-3^{*}$ & & & 1 & PC & $\mathrm{M}^{\mathrm{n}}$ & n.t. \\
\hline$P E P A-1 *$ & 3.4.-.- & Dimer & 1 & L,M,E,H & M & n.t. \\
\hline$P E P A-2 *$ & & & 1 & E & $\mathbf{M}$ & n.t. \\
\hline$P E P B^{*}$ & & Monomer & 1 & $\mathrm{~L}, \mathrm{M}, \mathrm{E}, \mathrm{H}$ & M & n.t. \\
\hline PEPD* & 3.4.13.9 & Dimer & 1 & L,M,E,H & $\mathbf{M}$ & n.t. \\
\hline$P E R^{*}$ & 1.11.1.7 & Unknown & 2 & L & n.s. ${ }^{r}$ & n.t. \\
\hline$P G D H^{*}$ & 1.1.1.44 & Dimer & 3 & $\mathbf{M}$ & $\mathbf{M}^{T}$ & +++ \\
\hline$P G K-1^{*}$ & 2.7 .2 .3 & Monomer & 2 & M & n.s. ${ }^{\mathrm{n}}$ & n.t. \\
\hline$P G K-2^{*}$ & & & 2 & H,M,E,B & $\mathbf{M}$ & n.t. \\
\hline$P G K-3^{*}$ & & & 2 & H,M,E,B & $\mathbf{M}$ & n.t. \\
\hline$P G M-1 *$ & 5.4.2.2 & Monomer & 2 & $\mathrm{~L}, \mathrm{M}$ & $\mathbf{M}^{\mathrm{r}}$ & ++ \\
\hline$P G M-2 *$ & & & 2 & $\mathrm{M}, \mathrm{L}$ & V & +++ \\
\hline$P G M-1 r^{*}$ & & & 2 & $\mathrm{~L}$ & $\mathbf{M}^{\mathrm{T}}$ & n.t. \\
\hline$P N P-1^{*}$ & 2.4.2.1 & Trimer & 2 & $\mathrm{~B}, \mathrm{E}$ & $\mathbf{M}$ & n.t. \\
\hline$P N P=2 *$ & & & 2 & $\mathrm{~B}, \mathrm{E}$ & $\mathbf{M}^{\mathrm{n}}$ & n.t. \\
\hline$S O D-1 *$ & 1.15.1.1 & Tetramer & 4,1 & $\mathrm{H}$ & n.s. & n.t. \\
\hline$S O D-2^{*}$ & & Dimer & 4,1 & L & $\mathbf{M}^{\mathrm{r}}$ & ++ \\
\hline$T P I-1^{*}$ & 5.3.1.1 & Dimer & 5 & $\mathrm{~L}, \mathrm{E}, \mathrm{H}, \mathrm{B}$ & $\mathbf{M}^{\mathrm{n}}$ & +++ \\
\hline TPI-2* & & & 5 & L,E,H,B & $\mathbf{M}^{\mathrm{n}}$ & +++ \\
\hline TPI-3* & & & 5 & L,E,B & $\mathrm{V}^{\mathrm{n}}$ & +++ \\
\hline$X D H^{*}$ & 1.1.1.204 & Dimer & 1,5 & $\mathrm{~L}$ & $\mathbf{M}$ & - \\
\hline
\end{tabular}

The buffer giving the best resolution and the tissue in which a locus was most highly expressed are listed. Whether or not a locus was variable (V/M) in the four index samples is also reported, while those loci only screened during technique development are denoted by n.s. Tissues are listed in decreasing order of activity. Only four tissues (liver, heart, muscle and eye) were assayed in the four index samples; better resolution was sometimes found in other tissues using the other samples. Activity in adipose fin (AF) is also listed.

$\dagger$ Enzyme stains are all reported in Aebersold et al. (1987) except for: $m M E^{*}$, Verspoor \& Jordon (1994); PER*, Hillis \& Moritz (1990); $X D H^{*}$, Morizot \& Schmidt (1990).

$\ddagger 1$, the modified discontinuous buffer of Ridgway et al. (1970) described in Morizot \& Schmidt (1990); 2, the $0.01 \mathrm{M}$ EDTA continuous buffer of Clayton \& Tretiak (1972) adjusted to $\mathrm{pH} 6.8 ; 2 \mathrm{a}, 1: 10$ dilution of gel buffer; 3 , the continuous buffer of Clayton \& Tretiak (1972) adjusted to $\mathrm{pH} 6.1 ; 4$, the discontinuous buffer no. 3 of Selander et al. $(1971) ; 5$, the modified continuous buffer of Holmes \& Masters (1970) described in Shaklee \& Keenan (1986); 6, the continuous buffer 'a' of Schaal \& Anderson (1974).

\#L: Liver; M: muscle, E: eye; H: heart; B: brain; PC: pyloric caecae.

$\S \mathrm{V}$ : variable; M: monomorphic; $\mathrm{n}$ : investigated here for the first time in $S$. salar; r, reported as variable in other studies (see Discussion for references).

$\uparrow-$, no activity; + , faint activity; ++ , some activity but not reliably scorable; +++ , strong activity, good resolution and reliably scorable; n.t., not tested.

BIOSYS-1 (Swofford \& Selander, 1981). Monomorphic loci were excluded from the data analysis apart from the calculation of overall levels of heterozygosity $(\bar{H})$ and polymorphism $(\bar{P})$ in the four index samples: several loci were screened only in the four index samples and not in those collected earlier. A locus was considered polymorphic if the frequency of the most common allele was 0.99 or less. Hetero- 
geneity among samples at each locus was estimated from the $F$-statistics of Wright (1978) and tested by $\chi^{2}=2 N F_{\text {ST }}$ (Workman \& Niswander, 1970) where $2 N$ is the total number of gametes tested; degrees of freedom are $(n-1)(s-1)$ where $n=$ number of alleles at a locus and $s=$ number of samples. Discrimination between pairs of samples and cluster analysis (UPGMA) was performed using Nei's (1978) unbiased genetic distance. The FORTRAN program of Black \& Krafsur (1985) was used to calculate twolocus linkage disequilibrium coefficients from the estimated gene frequencies.

\section{Results}

The six different buffer systems employed (Table 1) included three (nos 2, 5 and 6) not previously used in $S$. salar. Fifty-nine monomorphic and 13 variable enzyme loci were assayed in the four index samples (Table 1). A further 19 loci were successfully resolved but found to be monomorphic in the Brogeen sample; time did not allow for them to be investigated in the four index samples. The 91 loci, including 21 loci not previously screened in $S$. salar, are listed in Table 1 along with the subunit structure of each enzyme, the tissue specificity of each locus and whether a locus was found to be variable in the four index samples.

Variation at EST-5* (*90), FBALD-3* $\left({ }^{*} 50\right)$ and TPI-3* $\left({ }^{*} 103\right.$ and $\left.{ }^{*} 97\right)$ was found for the first time as a result of this study as described below.

Esterase. Five anodally migrating bands were apparent in most liver samples but an extra band, slightly slower than the most anodally migrating band, was found in seven individuals from the Shin. The scoring was consistent over several electrophoretic runs, indicating that these two bands were not the result of tissue degradation. The five-banded pattern was presumed to be the product of five loci and the variation detected at EST-5* was considered to be genetic. This locus had not previously been reported in the literature, although it may correspond to either the variable esterase Zone II or the monomorphic Zone I reported by Khanna et al. (1975b).

Fructose-bisphosphate aldolase. The five-banded pattern resolved in brain and eye tissue was presumed to be the product of FBALD-2*, FBALD. $3^{*}$ and their heterotetramers. The presence of 15-banded, and occasional five-banded, individuals with the same mobility of the least anodal band but with lower mobility of the four other bands was presumed to reflect diallelic polymorphism at FBALD-3*.

Triose-phosphate isomerase. A full description of the three TPI loci expressed in $S$. salar and the variation detected at TPI-3* is given in Wilson et al. (1995).

There were 14 other putative loci not previously reported as being screened in $S$. salar and these were found to be monomorphic (see Table 1).

A number of variant alleles at 10 other loci were detected in the index populations, of which two ( $s A A T-1,2^{*} 130$ in muscle and $s A A T-3^{*} 83$ in eye) appear to be reported here for the first time. Jordan (1990) reported $P G M-1{ }^{*}-120$ and ${ }^{*}-140$ variants and it is likely that these are the same as the PGM-2* alleles reported here. (The numbering of these two loci is here based on variation at the regulatory locus, PGM-1r*, in Oncorhynchus mykiss (Allendorf et al., 1982). A similar polymorphism is also present in North American populations of $S$. salar (Verspoor, 1988a) but in the more anodal of the two bands. Thus this band is designated $P G M-1^{*}$ whereas the variation detected here was at the least anodally migrating band, $P G M-2^{*}$.)

One individual from the Shin sample was found to be a trout-salmon hybrid from its $G P I^{*}$ genotype and was excluded from the analysis. Out of 36 tests for deviation from Hardy-Weinberg expectation the following were significant: farmed strain, $I D D H-2^{*}$ $(P<0.05$; excess of heterozygotes $)$ and IDHP-3* $(P<0.01$; excess of rare homozygotes); Shin, $I D D H$ $1^{*}(P<0.05$; excess of rare homozygotes). Given the number of tests, two samples would be expected to show significant deviation from random mating at the 0.05 level. In addition, when the level of significance was reset by using the Bonferroni technique for multiple tests (see Weir, 1990) the samples conformed to Hardy-Weinberg expectation.

Allele frequencies at the thirteen variable loci in the four index samples, the mean number of alleles $\left(n_{\mathrm{a}}\right)$ across these loci and the mean levels of $\bar{P}$ and $\bar{H}$ over the 72 loci screened in the four index samples are shown in Table 2 together with allele frequencies reported in the literature for the same locations. Variants at two of the novel loci $(F B A L D$. $3^{*}$ and $\left.T P I-3^{*}\right)$ were present in all four index samples whereas EST-5*90 was only found in the Shin sample. The novel variant alleles at previously reported loci were restricted to the Blackwater $\left(s A A T-1,2^{*} 130\right)$ and Shin $\left(s A A T-3^{*} 83\right)$. The allele $L D H-4^{*} 75$ may be the same as $L D H-4^{*} 68$ reported by Jordan (1990) for Scottish populations of $S$. salar.

(c) The Genetical Society of Great Britain, Heredity, 75, 578-588. 
Table 2 Frequencies of the less common alleles and $F_{\text {ST }}$ values at 13 variable enzyme loci among the four index samples of Salmo salar

\begin{tabular}{|c|c|c|c|c|c|c|c|c|c|c|c|}
\hline \multirow[b]{3}{*}{ Locus } & \multirow[b]{3}{*}{$F_{\mathrm{ST}}^{\dagger}$} & \multirow[b]{3}{*}{ Allele } & \multicolumn{9}{|c|}{ Sample $\ddagger$ (latitude) } \\
\hline & & & \multicolumn{3}{|c|}{$\begin{array}{c}\text { Esva } \\
\left(43^{\circ} \mathrm{N}\right)\end{array}$} & \multicolumn{2}{|c|}{$\begin{array}{l}\text { Blackwater } \\
\left(52^{\circ} \mathrm{N}\right)\end{array}$} & \multicolumn{2}{|c|}{$\begin{array}{l}\text { Shin } \\
\left(58^{\circ} \mathrm{N}\right)\end{array}$} & \multicolumn{2}{|c|}{$\begin{array}{l}\text { Farmed } \\
\left(60^{\circ} \mathrm{N}\right)\end{array}$} \\
\hline & & & 1992 & 1 & 2 & 1992 & 3 & 1992 & 4 & 1992 & 5 \\
\hline & & $N$ & 50 & & & 50 & & 49 & & 50 & \\
\hline$m M E P-2^{*}$ & $0.223 * * *$ & 125 & 0.07 & n.t. & n.t. & 0.44 & 0.45 & 0.60 & 0.61 & 0.68 & 0.61 \\
\hline$I D D H-1^{*}$ & $0.079^{* * *}$ & 28 & 0.27 & 0.02 & 0.01 & 0.09 & 0.05 & 0.03 & 0.00 & 0.08 & n.t. \\
\hline$I D H P-3 *$ & $0.073^{* * *}$ & 116 & 0.00 & 0.02 & 0.00 & 0.17 & 0.17 & 0.02 & 0.02 & 0.06 & n.t. \\
\hline \multirow[t]{2}{*}{ sAAT-4*\$ } & $0.072^{* * *}$ & 50 & 0.27 & 0.11 & 0.12 & 0.35 & 0.33 & 0.14 & 0.08 & 0.03 & 0.06 \\
\hline & & 25 & 0.00 & 0.00 & 0.00 & 0.01 & 0.00 & 0.02 & 0.05 & 0.07 & 0.01 \\
\hline EST-5* & $0.055^{* * *}$ & 90 & 0.00 & n.t. & n.t. & 0.00 & 0.00 & 0.07 & n.t. & 0.00 & n.t. \\
\hline$I D D H-2^{*}$ & $0.052^{* * *}$ & -72 & 0.27 & 0.04 & 0.03 & 0.32 & 0.42 & 0.25 & 0.21 & 0.52 & 0.53 \\
\hline FBALD-3* & $0.044^{* * *}$ & 50 & 0.29 & n.t. & n.t. & 0.10 & n.t. & 0.16 & n.t. & 0.10 & n.t. \\
\hline$T P I-3^{*}$ & $0.037^{* *}$ & 103 & 0.05 & n.t. & n.t. & 0.16 & n.t. & 0.20 & n.t. & 0.24 & n.t. \\
\hline$L D H-4^{*}$ & $0.023^{*}$ & 75 & 0.00 & 0.00 & 0.00 & 0.00 & 0.00 & 0.03 & 0.00 & 0.00 & 0.00 \\
\hline \multirow[t]{2}{*}{$M D H-3 *$} & 0.019 & 80 & 0.04 & 0.06 & 0.10 & 0.00 & 0.00 & 0.00 & 0.00 & 0.00 & 0.00 \\
\hline & & 75 & 0.01 & 0.00 & 0.00 & 0.00 & 0.01 & 0.01 & 0.00 & 0.04 & 0.01 \\
\hline$s A A T-1 *$ & 0.008 & 130 & 0.00 & n.t. & n.t. & 0.01 & 0.00 & 0.00 & n.t. & 0.00 & 0.00 \\
\hline$S A A T-3^{*}$ & 0.008 & 83 & 0.00 & n.t. & n.t. & 0.00 & n.t. & 0.01 & n.t. & 0.00 & n.t. \\
\hline \multirow[t]{5}{*}{$P G M-2^{*}$} & 0.006 & -120 & 0.00 & n.t. & n.t. & 0.01 & 0.00 & 0.00 & 0.00 & 0.00 & 0.00 \\
\hline & & -140 & 0.00 & n.t. & n.t. & 0.00 & 0.00 & 0.01 & 0.00 & 0.00 & 0.00 \\
\hline & & $n_{\mathrm{a}}$ & 1.6 & & & 1.8 & & 2.0 & & 1.7 & \\
\hline & & $\frac{n_{\mathrm{a}}}{P}$ & 0.097 & & & 0.125 & & 0.167 & & 0.111 & \\
\hline & & $\bar{H}$ & 0.027 & & & 0.034 & & 0.030 & & 0.029 & \\
\hline
\end{tabular}

Latitudes of sites are given in parentheses. Loci are listed in order of decreasing values of $F_{\mathrm{ST}}$. In addition, sample size $(N)$ and measures of allozyme variability represented by mean number of alleles per locus $\left(n_{\mathrm{a}}\right)$ across the 13 variable loci and mean levels of polymorphism $(\bar{P})$ and heterozygosity $(\bar{H})$ across 72 loci among the four index samples are also reported.

$\dagger^{*} P<0.05,{ }^{* *} P<0.005,{ }^{* * *} P<0.001$. $\$ 1$ and 2, Sánchez et al. (1991); 3, Cross \& Ward (1980); 4, Jordan (1990); 5, Ståhl (1987); n.t., not tested. § Sánchez et al. (1991) referred to this as Aat-2 and Blanco et al. (1992) referred to it as Aat-3.

The level of $\bar{P}$ was highest in the Shin sample and lowest in the Esva sample. The level of $\bar{H}$ was also lowest in the Esva sample but was highest in the Blackwater sample. The sample from the farmed strain was at the lower end of the ranges of $\bar{P}$ and $\bar{H}$ among the wild, native samples.

Wright's $F$-statistics (1978) were used to estimate levels of differentiation at each variable locus in the four index samples. In the absence of natural selection $F_{\mathrm{ST}}$ values should be similar at each locus (Lewontin \& Krakauer, 1973). All of these values were below 0.080 except that at $m M E P-2 *$ which was almost three times higher than the next highest value (Table 2). There was a significant amount of population differentiation shown by nine of the 13 loci.

Discrimination between pairs of samples was achieved by using Nei's (1978) unbiased genetic distance. Mean genetic distances $(\bar{D})$ showed that the farmed strain was more closely related to the sample from the Shin and that both of these were more closely related to the sample from the Blackwater than they were to that from the Esva (Fig. 1a), conforming to their geographical locations. In addition, there was a highly significant regression of $\bar{D}$ against geographical distance (Fig. $1 \mathrm{~b} ; F_{1,4}=27.42$; $P<0.01)$. However, this association is heavily dependent upon the frequency distribution of alleles at $m M E P-2^{*}$. When this locus was excluded from the analysis the slope coefficient was smaller than that for the thirteen loci, and the regression was, just, not significant (Fig. $1 \mathrm{~b} ; F_{1,4}=6.94 ; P=0.06$ ).

Of the 13 variable loci, $m M E P-2^{*}$ and TPI-3* showed a highly significant north-south cline in allele frequency (Fig. 1c; $F_{1,2}=181.6 ; P<0.01$ and $F_{1,2}=144.0 ; P<0.01$, respectively), the latter being 
(a)

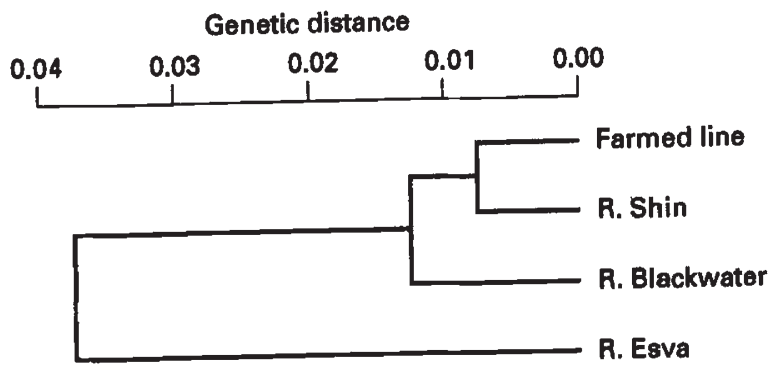

(b)

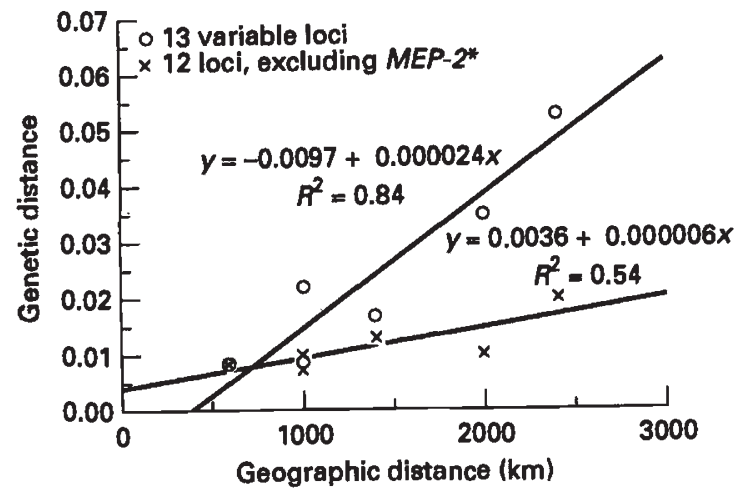

(c)

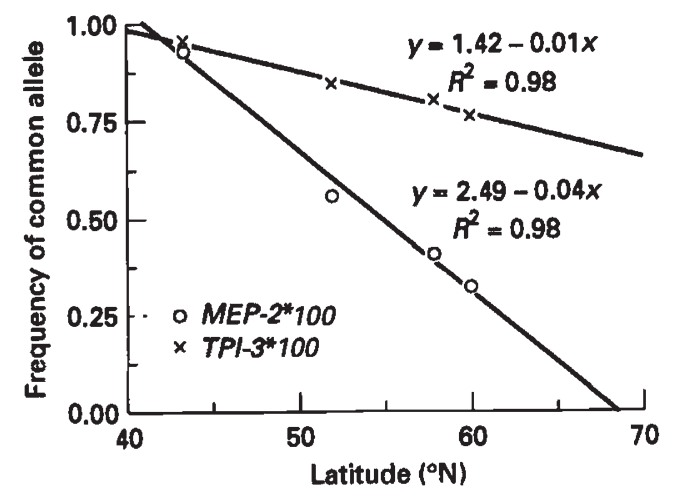

Fig. 1 (a) UPGMA dendrogram based on Nei's (1978) unbiased genetic distance from allele frequencies at 13 variable enzyme loci among the four index samples of Salmo salar. (b) Regression of genetic distance, based on 13 loci (open circles) and 12 loci excluding $M M E P-2^{*}$ (crosses), against geographical distance between all possible pairs of the four index samples. (c) Regression of frequency of $m M E P-2 * 100$ and TPI-3*100 against latitude.

less pronounced than the former. There were nonsignificant latitudinal clines in the frequencies of $I D D H-1 * 28 \quad(P<0.10)$ and $s A A T-4 * 25 \quad(P>0.20)$. Other loci showed no evidence of north-south clines in allele frequency.
There was no evidence of two-locus linkage disequilibrium between different alleles at the 13 polymorphic loci tested here.

The relative activities of 58 enzyme loci that were screened in adipose fin are reported in Table 1. Strong activity was found in this tissue at 14 loci, four of which were found to be variable in this study (IDHP-3*, LDH-4*, PGM-2* and TPI-3*). Notably, these four loci were also expressed in liver, in which nine of the 13 variable loci were detected. Twentytwo of 27 loci known to be variable in at least one population from throughout the range of $S$. salar and screened in this study were investigated in adipose fin, and six of these were well resolved. Nondestructive screening for genetic variation by using adipose fin would therefore provide about one-quarter of the information obtainable from muscle, liver and eye tissues.

\section{Discussion}

This paper reports the largest number of enzyme loci yet screened in a single study of $S$. salar. In addition to the 91 loci resolved here a further 19 loci have been screened by other workers: $A D A-2^{*}$ (liver; Cross \& Ward, 1980), $A K-3^{*}$ (muscle; Ståhl, 1981), EST-D* (Kazakov \& Titov, 1991), FDP-1*,$-2^{*}$ (muscle; McElligott, 1987), GDH* (liver; Ståhl, 1981), GAPDH-2* (eye; Cross \& Ward, 1980), G3PDH-2* (eye; Ståhl, 1981), -3* (liver; Cross \& Ward, 1980), -4* (liver; McElligott, 1987), G6PDH* (liver and eye; McElligott, 1987), bGUS* (liver; Ståhl, 1981), HK-1*, -2* (liver; Ståhl, 1981), $O D H^{*}$ (liver; Cross \& Ward, 1980), $T F^{*}$ (serum; Payne et al., 1971) and TRP-1* $-2^{*}$ and $-3^{*}$ (pyloric caecae; Torrissen, 1987). This brings to 110 the number of enzyme loci that have now been screened in $S$. salar, approaching the number screened in Pacific salmonids (J. B. Shaklee, personal communication).

In addition to the 13 variable loci reported here variants have been reported at 19 other loci (assuming that the variation is present at only one of the two loci in each isolocus): $m A A T-1,2^{*}$ (Elo et al., 1994); $A D A-2^{*}$ and $L G L^{*}$ (Cross \& Ward, 1980); $A D H^{*}, G 3 P D H^{*}, G P I-1,2^{*}, G P I-3^{*}, M D H-1^{*}$, $P G D H^{*}, P G M-1^{*}$ and $S O D-2^{*}$ (reviewed in Jordan, 1990); $C K-1^{*}$ and $P G M-1 r^{*}$ (Verspoor, 1988a); EST-D* and PER* (Kazakov \& Titov, 1991); LDH-5* (Khanna et al., 1975a); $m M E^{*}$ (Verspoor \& Jordan, 1994); TF* (Payne et al., 1971); TRP-2* (Torrissen, 1987). This brings to 32 the total number of variable enzyme loci reported in $S$. salar, excluding the seven esterase zones investigated by Khanna et al. (1975b). Therefore, about 29 per cent of allo- 
zyme loci have been found to be variable in at least one population from throughout the range of this species.

Parents in the crosses used to confirm the Mendelian inheritance of variation at TPI-3* (Wilson et al., 1995) were invariant at EST-5* and neither parental eye nor brain tissue was available so that the variation at $F B A L D-3^{*}$ could not be investigated further. However, genotype frequencies at these two loci in the four index samples conformed to Hardy-Weinberg expectations.

Levels of $\bar{H}$ across 72 loci were similar in the four index samples. However, the sample from the Shin segregated at between 33 and 72 per cent more loci and had between 11 and 25 per cent more alleles than the other samples. The mean level of $\bar{P}$ across the 72 loci screened in the four index samples was within the range reported by Ståhl (1987) from a smaller number of loci whereas the mean level of $\bar{H}$ was slightly higher than his estimate. In the present study as many loci as possible were screened and, therefore, the estimated mean levels of $\bar{P}(0.130)$ and $\bar{H}(0.030)$ among the three wild populations are probably more representative of the actual levels in $S$. salar than those reported by Ståhl (1987; $\bar{P}=0.093$ and $\bar{H}=0.026$ ) for 29 natural populations of this species from the western and eastern North Atlantic and the Baltic Sea. These values nevertheless confirm Atlantic salmon as one of the less variable salmonid species (reviewed in Johnson, 1984).

Allele frequencies were compared with those for each of the source populations reported in the literature (see Table 2). The farmed strain was compared with the southernmost Norwegian riverine sample reported by Ståhl (1987) as the majority of the broodstock used in the farming industry are derived from individuals originating from this region. For the Blackwater, Shin and farmed samples the most striking feature is the similarity of the allele frequencies. This indicates not only that different laboratories have obtained similar resolutions of alleles at many loci but also that the estimates of allele frequencies are similar over as much as 10 years between sample collections. However, allele frequencies at three loci $\left(I D D H-1^{*}, s A A T-4^{*}\right.$ and $\left.I D D H-2^{*}\right)$ in the Esva samples are different from those reported by Sánchez et al. (1991) which were used by Blanco et al. (1992) for a comparison of allele frequencies among European populations. When $\bar{D}$ values were calculated using the same four loci ( $S A A T-4^{*}$, IDDH-1*, IDHP-3* and $\left.M D H-3^{*}\right)$ used by Blanco et al. (1992) there was a nonsignificant positive regression of $\bar{D}$ on geographical distance (slope coefficient $=0.07 \times 10^{-5} ; F_{1,4}=2.19$; $P>0.20$ ), the slope coefficient being smaller than that reported by Blanco et al. (1992; coefficient $\left.=2.3 \times 10^{-5} ; P<0.001\right)$. This difference probably partly resulted from some of the allele frequencies reported by Blanco et al. (1992) being slightly inaccurate; the frequency of the common allele at $M d h-3$ is different from that reported by Cross \& Ward (1980), from which the former was taken, and the frequencies of the common alleles at Aat-3 and Mdh-3 reported by Blanco et al. (1992) are different from the original data of Sánchez et al. (1991).

Across a maximum possible distance by water of about $250 \mathrm{~km}$ between sample sites Elo et al. (1994) found no association between $\bar{D}$ over eight loci and geographical distance. However, a significant regression of $\bar{D}$ against geographical distance was found across the much larger distance investigated here.

The usefulness of particular enzyme loci in discriminating between populations was specific to each situation. As Shin salmon have been used for stocking the Esva (Morán et al., 1994) the following six loci, listed in decreasing order of value of singlelocus genetic distance $(D)$, would be of use in discriminating between them: $m M E P-2^{*}, I D D H-1^{*}$, TPI-3*, FBALD-3*, SAAT-4* and EST-5*. The farmed strain can be distinguished from at least one wild population at eight loci. One likely interaction is between farmed salmon derived from the strain screened here and wild salmon in the Blackwater. In that situation the following five loci, listed in decreasing order of $D$, would be useful genetic markers: $s A A T-4^{*}, \quad m M E P-2^{*}, I D D H-2^{*}$, IDHP-3* and $T P I-3^{*}$. In addition, $I D D H-2^{*}$ and, to a much lesser extent, $s A A T-4^{*}, \quad m M E P-2^{*}$ and EST-5* discriminated between the farmed strain and the wild salmon from the Shin.

It should be noted that a locus which was useful in distinguishing between one pair of samples was not necessarily discriminatory between all pairs of samples. The most consistently useful loci for discriminating between wild and farmed salmon were, in decreasing order of lowest $D$ between any pair of wild and farmed samples: IDDH $-2^{*}, s A A T-4^{*}$ and $M M E P-2^{*}$.

The novel enzyme markers developed during this research were more discriminatory, using $D$ for all possible pairwise comparisons of the index samples, than five of the loci commonly screened in $S$. salar (i.e. $s A A T-1^{*}, S A A T-3^{*}, L D H-4^{*}, M D H-3^{*}$ and $\left.P G M-2^{*}\right)$ but were not as discriminatory as $s A A T-4^{*}$, $I D D H-1^{*}, I D D H-2^{*}, I D H P-3^{*}$ and $M M E P-2^{*}$. 
The use of genetic markers in population studies depends on the assumption that they are not influenced by natural selection that may alter frequencies. However, there is evidence from other studies that alleles at $m M E P-2^{*}$ are selected differentially between areas of different mean July water temperatures (Verspoor \& Jordan, 1989). If the north-south cline in allele frequencies at $m M E P-2^{*}$ (Fig. 1c) was produced by stochastic factors then similar patterns should be discernible at other enzyme loci. Although there is a north-south cline in the frequency of TPI-3*100, the $F_{\mathrm{ST}}$ values at this and the other loci were at least 65 per cent less than that at $m M E P-2^{*}$. Therefore caution should be exercised in the use of $m M E P-2^{*}$ as a genetic marker. Nevertheless, if selection is weak then the use of this locus is justifiable in most situations as changes in allele frequencies between generations will be very slight. The cline in allele frequencies at TPI-3* requires further investigation as to whether it too may be maintained by natural selection.

A comparison was made between the UPGMA dendrogram obtained by including the three novel loci (Fig. 1a) and that obtained from the traditional loci only (not shown). $\bar{D}$ values between the samples were slightly smaller when the novel loci were included, reflecting the fact that variants at $F B A L D$ $3^{*}$ and TPI-3* were present in each sample. However, estimates of $\vec{D}$ among samples are likely to be more accurate when the novel loci are included. In addition, increasing the number of polymorphic loci reduced the variance in the estimates of $\vec{D}$ and thus will increase the accuracy of analysis of mixed fisheries (Pella \& Milner, 1987) and hybrids (Campton, 1987).

Moffett \& Crozier (1991) screened adipose fin tissue for expression of 10 polymorphic enzyme loci, finding $S O D-2^{*}$, unlike in the present study, to be well resolved. However, we were also able to resolve $I D H P-3^{*}$ and $P G M-2^{*}$ as well as $L D H-4^{*}, M D H-1^{*}$ and TPI-3*. A total of 59 loci (including G3PDH-2* from Moffett \& Crozier, 1991), i.e. half the total number of loci screened using destructive methods have now been screened in this tissue and seven polymorphic loci (including SOD-2*) have been resolved.

The three novel polymorphic loci discovered as a result of this study make it possible to estimate more accurately genetic differences between populations of $S$. salar. This should enable monitoring programmes to estimate with more confidence the origin of particular samples and the proportion of farmed escapes, their reproductive success in the wild and their genetic impact.

\section{Acknowledgements}

We thank the following for assistance: James Shaklee and the staff of the Washington Department of Fisheries; Michael Fanning and the staff of the Southern Regional Fisheries Board; Walter Crozier; Ken Bond, Nora Buttimer, Liam Corby, Emily Keating, Bob McNamara, Sandy O'Driscoll and Gertjan van Weeghel. This study was entirely supported by EC grant FAR MA-2-480.

\section{References}

AEBERSOLD, P. B., WINANS, G. A., TEEL, D. J., MILNER, G. B. AND UTTER, F. M. 1987. Manual for Starch Gel Electrophoresis: Complete Procedures for Detection of Genetic Variation. U. S. Department of Commerce, NOAA Technical report NMFS, no. 61. Seattle, WA.

ALLENDORF, F., KNUDSEN, K. L. AND PHELPS, S. R. 1982. Identification of a gene regulating the tissue expression of a phosphoglucomutase locus in rainbow trout. Genetics, 102, 259-268.

BLACK, W. C. AND KRAFSUR, E. S. 1985. A FORTRAN program for the calculation and analysis of two-locus linkage disequilibrium coefficients. Theor. Appl. Genet., 70, 491-496.

BLANCO, G., SÁNCHEZ, J. A., VÁZQUEZ, E., RUBIO, J. AND UTTER, F. M. 1992. Genetic differentiation among natural European populations of Atlantic salmon, Salmo salar L., from drainages of the Atlantic Ocean. Anim. Genet., 23, 11-18.

CAMPTON, D. 1987. Natural hybridisation and introgression in fishes: methods of detection and genetics interpretations. In: Ryman, N. and Utter, F. (eds) Population Genetics and Fishery Management, pp. 161-192. University of Washington Press, Seattle.

CLAYTON, J. W. AND TRETIAK, D. N. 1972. Amine-citrate buffers for $\mathrm{pH}$ control in starch gel electrophoresis. $J$. Fish. Res. Board Can., 29, 1169-1172.

CROSS, T. F. 1991. Potential genetic interactions between reared and wild fish in Europe, with particular emphasis on Atlantic salmon. In: De Pauw, N. and Joyce, J. (eds) Aquaculture and the Environment, pp. 299-308. European Aquaculture Society Special Publication no. 16 Gant, Belgium.

CROSS, T. F. AND PAYNE, R. H. 1977. NADP-isocitrate dehydrogenase polymorphism in the Atlantic salmon Salmo salar. J. Fish Biol., 11, 493-496.

CROSS, T. F. AND WARD, R. D. 1980 . Protein variation and duplicate loci in the Atlantic salmon, Salmo salar L. Genet. Res., 36, 147-165.

CROSS, T. F., WARD, R, D. AND ABREU-GROBOIS, A. 1979. Duplicate loci and allelic variation for mitochondrial malic enzyme in the Atlantic salmon, Salmo salar L. Comp. Biochem. Physiol., 62B, 403-406.

ELO, K., VUORINEN, J. A. AND NIEMELÄ, E. 1994. Genetic 
resources of Atlantic salmon (Salmo salar L.) in Teno and Näätämö Rivers, northernmost Europe. Hereditas, 120, 19-28.

FERGUSON, A. 1980. Biochemical Systematics and Evolution. Blackie, Glasgow.

GARCIA DE LEÁNIZ, C., VERSPOOR, E. AND HAWKINS, A. D. 1989. Genetic determination of the contribution of stocked and wild Atlantic salmon, Salmo salar L., to the angling fisheries in two Spanish rivers. J. Fish Biol., 35 (Suppl. A), 261-270.

HILLIS, D. M. AND MORITZ, C. 1990. Molecular Systematics. Sinauer Associates, Sunderland, MA.

HINDAR, K., RYMAN, N. AND UTTER, F. 1991. Genetic effects of aquaculture on natural fish populations. Can. J. Fish. Aquat. Sci., 48, 945-957.

HOLMES, R. S. AND MASTERS, C. J. 1970. Epigenetic interconversions of the multiple forms of mouse liver catalase. FEBS Lett., 11, 45-48.

JOHNSON, K. 1984. Protein Variation in the Salmoninae: Genetic Interpretations of Electrophoretic Banding Patterns, Linkage Associations Among Loci, and Evolutionary Relationships Among Species. Ph.D. Thesis, Pennsylvania State University.

JORDAN, w. C. 1990. Gene Flow Among Atlantic Salmon (Salmo salar) Populations in Scotland. Ph. D. Thesis, The Queen's University of Belfast, Northern Ireland.

KAZAKOV, R. V. AND TITOV, S. F. 1991. Geographical patterns in the population genetics of Atlantic salmon, Salmo salar L., on U.S.S.R. territory, as evidence for colonization routes. J. Fish Biol, , 39, 1-6.

KHANNA, N. D., JUNEJA, R. K., LARSSON, B. AND GAHNE, B. 1975a. Electrophoretic studies on proteins and enzymes in the Atlantic salmon, Salmo salar, L. Swedish J. Agric. Res., 5, 185-192.

KHANNA, N. D., JUNEJA, R. K., LARSSON, B. AND GAHNE, B. 1975b. Electrophoretic studies on esterases in the Atlantic salmon, Salmo salar, L. Swedish J. Agric. Res., 5, 193-197.

LEWONTIN, R. C. AND KRAKAUER, J. 1973. Distribution of gene frequency as a test of the theory of the selective neutrality of polymorphisms. Genetics, 74, 175-195.

McELLIGOTT, E. A. 1987. A Genetic Investigation of the Population Structure of Wild and Hatchery Reared Atlantic Salmon (Salmo salar L.) in Ireland. M.Sc. Thesis, University College Cork, Ireland.

MaITLAND, P. s. 1989. The Genetic Impact of Farmed Atlantic Salmon on Wild Populations. Nature Conservancy Council, Edinburgh.

MOFFETT, I. J. J. AND CROZIER, w. w. 1991. Genetic marker identification in Atlantic salmon (Salmo salar L.) by electrophoretic analysis of low risk tissues. J. Fish Biol., 39, 609-611.

MORÁN, P., PENDÁS, A. M., GARCíA-VÁZQUEZ, E., IZQUIERDO, J. T. AND RUTHERFORD, D. T. 1994. Electrophoretic assessment of the contribution of transplanted Scottish Atlantic salmon (Salmo salar) to the Esva River (northern Spain). Can. J. Fish. Aquat. Sci., 51, 248-252.

MORIZOT, D. C. AND SCHMIDT, M. E. 1990. Starch gel electrophoresis and histochemical visualization of proteins. In: Whitmore, D. H. (ed.) Electrophoretic and Isoelectric Focusing Techniques in Fisheries Management, pp. 23-80. CRC Press, Boca Raton, FL.

NEI, M. 1978. Estimation of average heterozygosity and genetic distance from a small number of individuals. Genetics, 89, 583-590.

PAYNE, R. H., CHILD, A. R. AND FORREST, A. 1971. Geographical variation in the Atlantic salmon. Nature, 231, 250-252.

PELLA, J. J. AND MILNER, G. B. 1987. Use of genetic marks in stock composition analysis. In: Ryman, $\mathbf{N}$. and Utter F. (eds) Population Genetics and Fishery Management, pp. 247-276. University of Washington Press, Seattle.

RIDGWAY, G. J., SHERBURNE, S. W. AND LEWIS, R. D. 1970. Polymorphism in the esterases of Atlantic herring. Trans. Am. Fish. Soc., 99, 147-151.

SÁNCHEZ, J. A., BLANCO, G., VÁZOUEZ, E., GARCÍA, E. AND RUBIO, J. 1991. Allozyme variation in natural populations of Atlantic salmon in Asturias (northern Spain). Aquaculture, 93, 291-298.

SCHAAL, B. A. AND ANDERSON, w. w. 1974. An Outline of Techniques for Starch Gel Electrophoresis of Enzymes from the American Oyster Crassostrea virginica Gmelin. Technical report of the Georgia Marine Science Center, no. 74-3 Skidaway Island, GA.

SELANDER, R. K., SMITH, M. H., YANG, S. Y., JOHNSON, W. E. AND GENTRY, J. B. 1971. Biochemical polymorphism and systematics in the genus Peromyscus. I. Variation in the old field mouse (Peromyscus polionotus). Stud. Genetics VI. Univ. Texas Publ., 7103, 49-90.

SHAKLEE, J. B. AND KEENAN, C. P. 1986. A Practical Laboratory Guide to the Techniques and Methodology of Electrophoresis and its Application to Fish Fillet Identification Report no. 177, CSIRO Marine Laboratories, Hobart, Tas., Australia.

SHAKLEE, J. B., ALLENDORF, F. W., MORIZOT, D. C. AND WHIT, G. S. 1990 . Gene nomenclature for proteincoding loci in fish. Trans. Am. Fish. Soc., 119, 2-15.

SHAKLEE, J. B., KLAYBOR, D. C., YOUNG, S. AND WHITE, B. A. 1991. Genetic stock structure of odd-year pink salmon (Oncorhynchus gorbuscha, Walbaum) from Washington and British Columbia and potential mixed-stock fisheries applications. J. Fish Biol., 39 (Suppl. A), 21-34.

SKAALA, Ø., DAHLE, G., JøRSTAD, K. E. AND NAVDAL, G. 1990. Interactions between natural and farmed fish populations: information from genetic markers. J. Fish Biol., 36, 449-460.

STÅHL, G. 1981. Genetic differentiation among natural populations of Atlantic salmon (Salmo salar) in Northern Europe. In: Ryman, N. (ed.) Fish Gene Pools, pp. 95-105. Ecological Bulletins, Stockholm, no. 34. Editorial Service, FRN. Stockholm, Sweden.

STÅHL, G. 1987. Genetic population structure of Atlantic salmon. In: Ryman, N and Utter, F. (eds) Population Genetics and Fishery Management, pp. 121-140. University of Washington Press, Seattle.

SWOFFORD, D. L. AND SELANDER, R. B. 1981. BIOSYS-1. $A$ Computer Program for the Analysis of Allelic Variation in

(C) The Genetical Society of Great Britain, Heredity, 75, 578-588. 
Genetics. Users Manual. Department of Genetics and Development, University of Illinois at Urbana-Champaign, IL.

TORRISSEN, K. R. 1987. Genetic variation of trypsin-like isozymes correlated to fish size of Atlantic salmon (Salmo salar). Aquaculture, 62, 1-10.

VERSPOOR, E. 1988a. Reduced genetic variability in firstgeneration hatchery populations of Atlantic salmon (Salmo salar). Can. J. Fish. Aquat. Sci. 45, 1686-1690.

VERSPOOR, E. 1988b. Identification of stocks in the Atlantic salmon. In: Stroud, R. H. (ed.) Proceedings of the Symposium on Future Atlantic Salmon Management, pp. 37-46. Marine Recreational Fisheries Series, National Coalition for Marine Conservation, Savannah, GA.

VERSPOOR, E. AND JORDAN, w. C. 1989. Genetic variation at the $M e-2$ locus in the Atlantic salmon within and between rivers: evidence for its selective maintenance. J. Fish Biol., 35, 205-213.

VERSPOOR, E. AND JORDAN, w. c. 1994. Detection of an $\mathrm{NAD}^{+}$-dependent malic enzyme locus in the Atlantic salmon Salmo salar and other salmonid fish. Biochem. Genet., 32, 105-117.
Verspoor, E. AND REDdin, D. G. 1989. A Model for the Classification of Atlantic salmon Salmo salar to Continent of Origin Using Genetic Protein Variation. ICES CM 1989/North Atlantic Salmon Working Group. The International Council for the Exploration of the Seas, Copenhagen, Denmark.

VUORINEN, J. AND PIIRONEN, J. 1984. Electrophoretic identification of Atlantic salmon (Salmo salar), brown trout (S. trutta), and their hybrids. Can. J. Fish. Aquat. Sci., 41, 1834-1837.

WEIR, B. S. 1990. Genetic Data Analysis. Sinauer Associates, Sunderland, MA.

WILSON, 1. F., BOURKE, E. A. AND CROSS, T. F. 1995. A triose-phosphate isomerase polymorphism in the Atlantic salmon, Salmo salar L. Biochem. Genet., 33, 25-33.

WORKMAN, P. L. AND NISWANDER, J. D. 1970. Population studies on south-western Indian tribes. II. Local genetic differentiation in the Papago. Am. J. Hum. Genet., 22, 24-49.

WRIGHT, S. 1978. Evolution and the Genetics of Populations, vol. 4, Variability Within and Among Natural Populations. University of Chicago Press, Chicago. 